\title{
Glial Growth Factor Rescues Schwann Cells of Mechanoreceptors from Denervation-Induced Apoptosis
}

\author{
Diane M. Kopp, Joshua T. Trachtenberg, and Wesley J. Thompson \\ Department of Zoology, University of Texas at Austin, Austin, Texas 78712
}

Golgi tendon organs and Pacinian corpuscles are peripheral mechanoreceptors that disappear after denervation during a critical period in early postnatal development. Even if regeneration is allowed to occur, Golgi tendon organs do not reform, and the reformation of Pacinian corpuscles is greatly impaired. The sensory nerve terminals of both types of mechanoreceptors are closely associated with Schwann cells. Here we investigate the changes in the Schwann cells found in Golgi tendon organs and Pacinian corpuscles after nerve resection in the early neonatal period. We report that denervation induces the apoptotic death of these Schwann cells and that this apoptosis can be prevented by administration of a soluble form of neuregulin, glial growth factor 2 . Schwann cells associated with these mechanoreceptors are immunoreactive for the neuregulin receptors erbB2, erbB3, and erbB4, and the sensory nerve terminals are immunoreactive for neuregulin. Our results suggest that Schwann cells in developing sensory end organs are trophically dependent on sensory axon terminals and that an axon-derived neuregulin mediates this trophic interaction. The denervation-induced death of mechanoreceptor Schwann cells is correlated with deficiencies in the re-establishment of these sensory end organs by regenerating axons.

Key words: Pacinian corpuscle; Golgi tendon organ; mechanoreceptor; Schwann cell; denervation; neuregulin; glial growth factor; apoptosis
Golgi tendon organs are muscle tension receptors, and Pacinian corpuscles are vibration detectors (for review, see Munger and Ide, 1987; Jami, 1992). The sensory nerve endings of both of these mechanoreceptors are associated with Schwann cells (Spencer and Schaumburg, 1973; Zelená and Soukup, 1977; Zelená, 1978). Ultrastructural examinations of tendon organs suggest that terminal branches of the afferent nerve are covered by nonmyelinating Schwann cells (Zelená and Soukup, 1977). In the Pacinian corpuscle, layers of specialized Schwann cells wrap the afferent terminal (Spencer and Schaumburg, 1973; Zelená, 1978), and only a few of these cells participate in myelination of a portion of the axon (Zelená, 1978). Schwann cells associated with afferent endings of mechanoreceptors therefore appear similar to terminal Schwann cells, the nonmyelinating Schwann cells covering the motor axon terminal at the neuromuscular junction (Son et al., 1996).

For many types of mechanoreceptors, the survival of their non-neuronal constituents is influenced by the presence of sensory axons (Zelená, 1994). Ten days after denervation of the soleus muscle in the neonate, no tendon organs are discernible (Zelená and Hnik, 1963a). After nerve crush, tendon organs fail to reform, although axons regenerate (Zelená and Hnik, 1963b). Neonatal Pacinian corpuscles also disappear after loss of contact with axons (Zelená et al., 1978; Zelená 1980). Denervation at

Received April 21, 1997; revised June 4, 1997; accepted June 10, 1997.

This work was supported by a grant from the Paralyzed Veterans of America to D.M.K., National Institutes of Health Grant NS 20480, and a grant from the Amyotrophic Lateral Sclerosis Society of America. We thank C. Kirk and M. Marchionni at Cambridge Neuroscience Inc. for the generous gift of GGF2 and C.

Lai for providing us with the affinity purified form of antibody 616 to erbB4, as well as its immunizing peptide.

Correspondence should be addressed to Diane M. Kopp, University of Texas at Austin, Department of Zoology, PAT 312, Austin, TX 78712.

Dr. Trachtenberg's present address: Department of Physiology, University of California Medical School, San Francisco, CA 94143.

Copyright (C) 1997 Society for Neuroscience $0270-6474 / 97 / 176697-10 \$ 05.00 / 0$ postnatal day $0(\mathrm{P} 0)$ or $\mathrm{P} 1$ results in the complete disintegration of corpuscles by P6 (Zelená, 1980). After nerve crush, a few corpuscles can form de novo; however, their morphology and reinnervation are extremely impaired (Zelená, 1981). One explanation for why neonatal mechanoreceptors are sensitive to denervation may be related to an early trophic dependence. Adult corpuscles and muscle mechanoreceptors survive denervation (Zelená and Hnik, 1963b; Zelená, 1982), suggesting that they are no longer dependent on nerve-derived factors for their maintenance.

Similar developmentally regulated deficiencies in reinnervation occur at mammalian neuromuscular junctions: adult junctions are readily reinnervated, whereas reinnervation in neonates is deficient. Correlated with this developmental difference is a change in the behavior of terminal Schwann cells present at the junctions. In adults, terminal Schwann cells extend processes in response to denervation (Reynolds and Woolf, 1992). These processes promote nerve regeneration by providing substrates for nerve growth (Son and Thompson, 1995a,b). In neonatal animals, the terminal Schwann cells die by apoptosis after denervation and thus are not present to support muscle reinnervation (Trachtenberg and Thompson, 1996).

We have investigated whether Schwann cells in neonatal mechanoreceptors behave like terminal Schwann cells at neonatal neuromuscular junctions. We show that Schwann cells of Golgi tendon organs and Pacinian corpuscles in neonatal rats die by apoptosis after nerve resection. Application of a neuregulin, glial growth factor 2 (GGF2), immediately after denervation prevents Schwann cell death in vivo, suggesting that this factor mediates the trophic dependence of these cells on axons. Schwann cells associated with these mechanoreceptors are immunoreactive for the neuregulin receptors erbB2, erbB3, and erbB4. Furthermore, the sensory nerve terminals of these mechanoreceptors are immunoreactive for neuregulin. Thus, axon-derived neuregulins 
seem to play important roles in the maintenance and differentiation of neonatal mechanoreceptors. Death of Schwann cells in tendon organs and Pacinian corpuscles may be at least partially responsible for the impaired ability of these mechanoreceptors to reform after sensory axon regeneration.

\section{MATERIALS AND METHODS}

Animals and surgery. All rats were of the Wistar strain, and all surgeries were performed aseptically under ether anesthesia. Golgi tendon organs were examined in soleus muscles, and Pacinian corpuscles were examined in interosseus membranes. A large population of Pacinian corpuscles ( $\sim 50$; see Results) is associated with the distal portion of the interosseous nerve. This nerve runs through the interosseus membrane located between the tibia and fibula and ramifies in the periosteum of the lower fibula (Zelená, 1976). Denervations of muscles or membranes were by unilateral resection of a $\sim 2 \mathrm{~mm}$ piece from the sciatic nerve, and wounds were sutured with silk.

To examine the effects of neuregulin on Golgi tendon organs after axotomy, animals were denervated at $\mathrm{P} 4$ and immediately received two subcutaneous injections of $5 \mu \mathrm{l}$ each of either human recombinant GGF2 (Cambridge Neuroscience; $0.18 \mu \mathrm{g} / \mu \mathrm{l}$ final concentration in a vehicle solution of $20 \mathrm{~mm} \mathrm{NaAc}, 100 \mathrm{~mm}$ arginine, $1 \%$ mannitol, $100 \mathrm{~mm} \mathrm{Na}_{2} \mathrm{SO}_{4}$ and $1 \mathrm{mg} / \mathrm{ml}$ bovine serum albumin (BSA); half-maximum activity for Schwann cell proliferation, $6.8 \mathrm{ng} / \mathrm{ml}$ ) or the vehicle solution alone in the denervated hindlimb. One injection was on the lateral aspect of the calf, and the other was on the medial side. Pups were killed $24 \mathrm{hr}$ later at P5, others received injections for 1 or $2 \mathrm{~d}$ more and were subsequently killed at $\mathrm{P} 6$ or P7, respectively. For examination of Pacinian corpuscles, sciatic nerve resections were performed at $\mathrm{P} 2$, and animals were examined at P5 or P6. Some animals received GGF2 injections administered as described above, except every $12 \mathrm{hr}$. Subcutaneous injections of either GGF2 or vehicle solution were directed to the lateral and medial aspects of the calf just above the ankle.

Antibodies. The following antibodies were used in this study for immunohistochemistry on whole soleus muscles, whole interosseus membranes, or $10 \mu \mathrm{m}$ cryostat sections of interosseus membranes: rabbit polyclonal anti-cow-S-100 (Z0311; Dako, Carpinteria, CA) used at 1:400; mouse hybridoma supernatant $2 \mathrm{H} 3$, which recognizes a $165 \mathrm{kDa}$ neurofilament protein (Developmental Studies Hybridoma Bank, Baltimore, MD and Iowa City, IA) used at 1:200; mouse monoclonal antisynaptophysin (S-5768; Sigma, St. Louis, MO) used at 1:400; rabbit polyclonal anti-erbB2 directed against amino acids $1243-1255$ from the C terminus of the human c-erbB2/HER-2 oncoprotein (RB-103-P; Neomarkers, Inc., Fremont, CA) used at 1:100; rabbit polyclonal anti-erbB3 directed against amino acids $1307-1323$ from the $\mathrm{C}$ terminus region of the precursor form of human erbB3 p160 (C-17, SC-285; Santa Cruz Biotechnology Inc., Santa Cruz, CA) used at 1:100; rabbit polyclonal anti-erbB4 directed against amino acids $1285-1308$ from the $\mathrm{C}$ terminus region of human c-erbB4/HER-4 (RB-284-P; Neomarkers, Inc.) used at 1:100; affinity-purified rabbit polyclonal antibody 616 (kindly provided by Dr. C. Lai, Scripps Research Institute) prepared against a glutathione $S$-transferase fusion protein containing a peptide sequence corresponding to residues $1185-1238$ from the $\mathrm{C}$ terminus of human erbB4 (Plowman et al., 1993) used at 1:100; and rabbit polyclonal anti-heregulin/Neu differentiation factor/GGF/neuregulin directed against an amino acid sequence from the epidermal growth factor (EGF)-like domain of human heregulin (RB-277-P; Neomarkers, Inc.) used at 1:100. Secondary antibodies included a fluorescein-conjugated sheep $\mathrm{F}\left(\mathrm{ab}^{\prime}\right) 2$ fragment antimouse (absorbed against rat serum proteins; F-2266; Sigma) used at $1: 100$ and rhodamine-conjugated goat $\mathrm{F}\left(\mathrm{ab}^{\prime}\right) 2$ fragment anti-rabbit (whole molecule; 55671; Cappel, Durham, NC) used at 1:400.

Staining for the neuregulin receptors erbB2 and erbB3 was eliminated by preadsorption of each antibody with a 10-fold excess of the appropriate control peptide (PP-103 for erbB2; Neomarkers, Inc.; SC-285P for erbB3, Santa Cruz Biotechnology Inc.). No control peptide is available for anti-erbB4 (RB-284-P; Neomarkers Inc.); positive immunoreactivity for the erbB4 antibody 616 was eliminated by use of its immunizing peptide (C. Lai; $1 \mu \mathrm{l} / 10 \mu \mathrm{l}$ antibody).

Immunocytochemistry protocols. The procedures for conventional immunostaining of whole mounts were basically those reported previously (Astrow et al., 1994) with minor alterations. Dissected whole muscles and whole or cryostat sections of interosseus nerves and membranes were fixed for $10 \mathrm{~min}$ in $4 \%$ paraformaldehyde in $0.1 \mathrm{M}$ phosphate buffer, rinsed in PBS for $30 \mathrm{~min}$, permeabilized by immersion in absolute $\mathrm{MeOH}$ for $6 \mathrm{~min}$ at $-20^{\circ} \mathrm{C}$, rinsed in PBS for $30 \mathrm{~min}$, and blocked for $30 \mathrm{~min}$ in a solution (diluent) consisting of $0.3 \%$ Triton $\mathrm{X}-100,0.2 \%$ bovine serum albumin (BSA), and $0.1 \%$ sodium azide in PBS. For single or double labels, all antibodies were then prepared in the diluent, and tissues were immunostained overnight at room temperature on a shaker plate. Tissue was rinsed in diluent for $30 \mathrm{~min}$, and the appropriate secondary antibodies were applied for $1 \mathrm{hr}$. After a final $30 \mathrm{~min}$ rinse in PBS, muscles were cleared of connective tissue from their surface, and a thin sheet of fibers was carefully peeled away from the lateral and medial surfaces. Muscle sheets or interosseus nerves and membranes were mounted in fluorescence mounting media (FITC-Guard; Testog, Chicago, IL).

Some preparations were double-labeled with antibodies to S-100 for Schwann cells and erbB3, one of the neuregulin receptors. Both antibodies are rabbit polyclonals, and the technique of "dilutional neglect" was used to differentiate the two (Shindler and Roth, 1996). This technique involved the use of the Renaissance TSA-Direct (red) tryramide signal amplification kit (Dupont NEN, Boston, MA). Briefly, muscles and interosseus membranes were prepared for conventional immunohistochemistry as described above; however, the blocking solution (high-BSA diluent) contained $0.3 \%$ Triton $\mathrm{X}-100,1.0 \%$ BSA, $0.2 \%$ powdered milk, and $0.1 \%$ sodium azide in PBS. Anti-erbB3 was applied to the tissues first. It was diluted 1:4000 in high BSA diluent, a dilution determined in preliminary experiments to result in no detectable immunostaining by conventional immunofluorescence procedures (as described above; data not shown), yet a concentration at which rhodamine-tyramide amplification results in a very bright signal. With conventional immunofluorescence, this antibody is routinely used at 1:100, and no signal is detected at dilutions $<1: 1000$. Tissue was incubated overnight at room temperature, rinsed in high BSA diluent for $30 \mathrm{~min}$, and then incubated for $1 \mathrm{hr}$ in biotinylated goat $\mathrm{F}\left(\mathrm{ab}^{\prime}\right) 2$ fragment anti-rabbit antibody (whole molecule; 55701; Cappel) diluted 1:750 in high BSA diluent. Tissue was rinsed for $30 \mathrm{~min}$ in PBS and then incubated for $30 \mathrm{~min}$ in TNB $(0.1 \mathrm{M}$ Tris- $\mathrm{HCl}, \mathrm{pH} 7.5,0.15 \mathrm{M} \mathrm{NaCl}$, and $0.5 \%$ DuPont blocking reagent). Tissue was then incubated in streptavidin-HRP diluted 1:500 in TNB and rinsed for $30 \mathrm{~min}$ in Tris buffer $(0.1 \mathrm{M}$ Tris- $\mathrm{HCl}, \mathrm{pH} 7.5$, and $0.15 \mathrm{M}$ $\mathrm{NaCl}$ ). Rhodamine-tyramide diluted 1:1000 in DuPont $1 \mathrm{X}$ amplification diluent was applied to the tissue for $10 \mathrm{~min}$. The reaction was stopped by rinsing the tissue with Tris buffer for $30 \mathrm{~min}$, followed by PBS for $20 \mathrm{~min}$. Tissue was blocked in high-BSA diluent a second time for $30 \mathrm{~min}$, and anti-S-100 (1:400) followed by a fluorescein-conjugated goat anti-rabbit secondary antibody was applied using procedures described above for conventional immunofluorescence. Tissues were cleaned and mounted as described. Specificity of erbB3 staining was confirmed by preincubating the antisera with immunizing peptide (see above) and repeating the procedure.

The rhodamine-tyramide amplification technique was also used in a single-label protocol to enhance otherwise weak but present labeling obtained by conventional immunohistochemical methods for each of the erbB receptors in cryostat sections of Pacinian corpuscles in interosseus membranes. With this technique, the erbB2 and erbB4 antibodies were used at dilutions of 1:500, and the erbB3 antibody was used at 1:4000. The rhodamine-tyramide reaction was limited to $5 \mathrm{~min}$ for tissue sections. Specificity of staining was confirmed using the appropriate control peptides as described above. In addition, using the amplification technique in the absence of primary antibody, no labeling was observed.

Detection of apoptotic Schwann cells. For the detection of apoptotic Schwann cells, preparations were first stained by conventional immunofluorescence techniques with anti-S-100 and the rhodamine-conjugated secondary antibody as described. Preparations were then labeled using the fluorescein-conjugated ApopTag in situ apoptosis detection kit (Oncor, Gaitersburg, MD) to identify nuclei undergoing DNA fragmentation characteristic of apoptotic cells. For the quantitative assessment of apoptotic Schwann cells, TdT-mediated dUTP nick end labeling (TUNEL)labeled nuclei were only counted if they were present in cells also labeled with anti-S-100. Apoptotic cells were counted in all Golgi tendon organs examined per muscle and in 20 Pacinian corpuscles per preparation. All numbers are expressed as mean $\pm \mathrm{SD}$.

Imaging and documentation. All preparations were examined on a Leica or Nikon epifluorescence microscope with an integrating CCD camera connected to a Macintosh computer equipped with a frame grabber and running National Institutes of Health Image software. Where indicated, some images are maximum projections of many, single optical slices obtained with a Leica TCS 4D confocal microscope. 

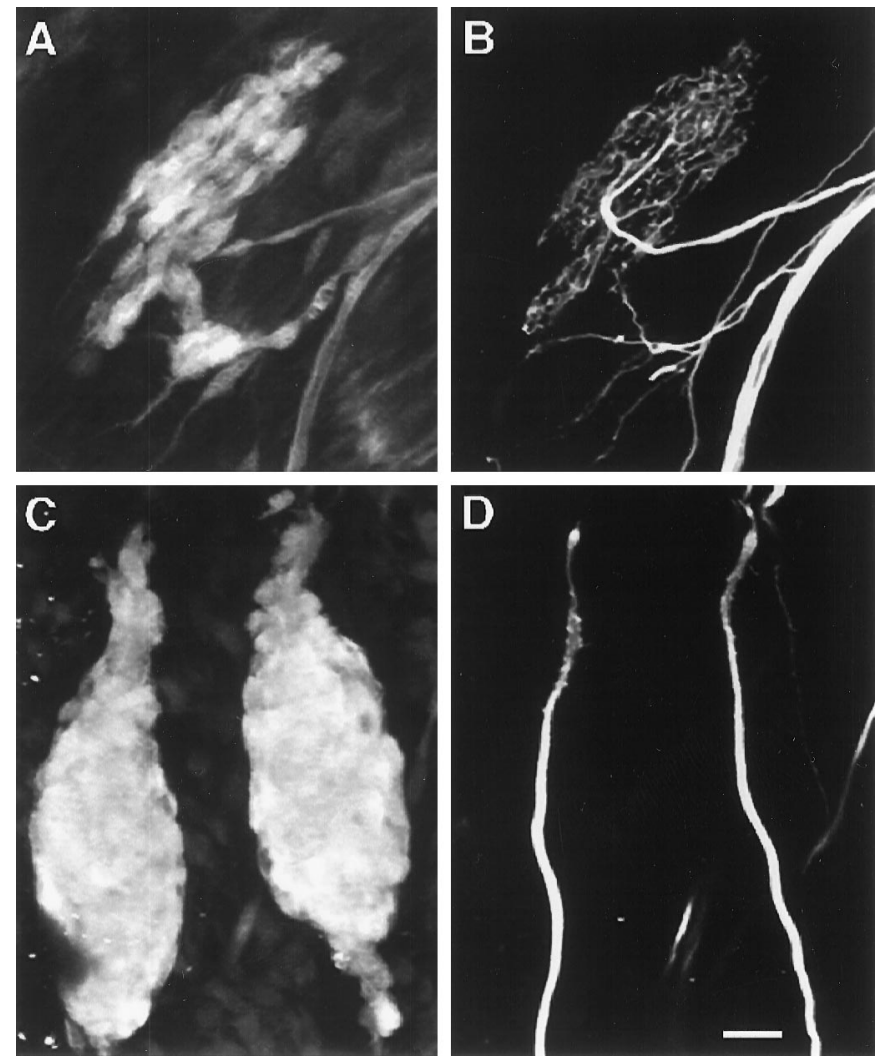

Figure 1. Sensory terminals of Golgi tendon organs and Pacinian corpuscles are closely associated with Schwann cells. Although there is no direct evidence that the sensory terminals of these mechanoreceptors act as presynaptic release sights for synaptic vesicles, they have both dense and clear core vesicles (Spencer and Schaumburg, 1973; Zelená and Soukup, 1977; Zelená, 1978) and label with the synaptophysin antibody (also see De Camilli et al., 1988). Therefore, we used anti-synaptophysin in conjunction with anti-neurofilament to enhance labeling of the complete afferent nerve arborizations. $A, B$, Confocal images of Schwann cells of a P6 Golgi tendon organ ( $A$, stained for S-100) and the nerve terminal arborization ( $B$, stained for neurofilament and synaptophysin). Normal innervation is by a single myelinated axon, and occasionally, as shown here in the lower left, there are closely associated accessory axons that form free endings near the receptor (Barker, 1974). $C, D$, Confocal images of inner cores (Schwann cells) of two P5 Pacinian corpuscles $(C$, stained for S-100) and their centrally located nerve terminals $(D$, stained for neurofilament and synaptophysin). The tips of the terminals are bulbous nerve endings shown near the top of $D$. Scale bar, $20 \mu \mathrm{m}$ for all panels.

\section{RESULTS}

\section{Immunoreactivity of mechanoreceptor Schwann cells}

Immunocytochemistry for the calcium-binding protein and general Schwann cell marker, S-100, in conjunction with antibodies to neurofilament and synaptophysin revealed both the intricate nerve terminal arborization of the Golgi tendon organ and its relationship to Schwann cells. The afferent nerve arbor is completely covered by S-100-positive cells and their short processes (Fig. $1 A, B$ ), consistent with previous ultrastructural observations (Zelená and Soukup, 1977).

Similar to tendon organs, labeling of Pacinian corpuscles with anti-S-100, anti-neurofilament, and anti-synaptophysin revealed that the single afferent terminal of each mechanoreceptor is surrounded by a dense layer of S-100-positive cells, which previous investigators have called inner core cells (Fig. 1C,D). Ultrastructural studies have suggested previously that the cells that surround the afferent terminal differentiate from Schwann cells that accompany the sensory axon during the early development of the mechanoreceptor (Zelená, 1978). S-100 labeling of the inner core cells in this study and others (Iwanaga et al., 1982; Vega et al., 1990; Takahashi, 1995) provides further evidence that these cells originate from Schwann cells.

\section{Denervation induces apoptosis of mechanoreceptor Schwann cells}

Neonatal sciatic nerve axotomy results in the disappearance of Golgi tendon organs and Pacinian corpuscles (see Tables 1, 2, respectively). The average number of tendon organs per soleus muscle at P7 is 14; however, in P7 muscles that had been denervated by sciatic nerve resection at $\mathrm{P} 4$, no structurally intact tendon organs were present (Table 1). Some of the Schwann cells that presumably had previously myelinated the sensory nerves that lead up to the end organs were still intact in the tendonous regions of the muscle. Although their organization resembled that of the sensory nerves in this region of a normal muscle, these Schwann cells ended blindly in the tendon region of the denervated muscle and did not terminate in the clustered pattern of Schwann cells that normally resembled an end organ. They were also only weakly stained with anti-S-100. Similar to tendon organs, sciatic nerve resection at $\mathrm{P} 2$ resulted in a complete loss of Pacinian corpuscles by late P6. The normal complement of corpuscles at this age is $\sim 50$ (Table 2 ). In the denervated preparations, six brightly labeled S-100-positive clusters of two to four cells each were present in the vicinity of the interosseus nerve; however, confident identification of these structures as Pacinian corpuscles could not be made.

A previous study (Zelená, 1980) reported that the denervationinduced loss of the inner core cells of the Pacinian corpuscle is correlated with morphological changes in these cells that include the appearance of dense inclusion bodies and vacuoles with cellular debris. To examine the possibility that the disappearance of Schwann cells in Golgi tendon organs and Pacinian corpuscles after denervation resulted from their death rather than a loss of S-100 immunoreactivity, we used the TUNEL technique to identify DNA fragmentation in nuclei undergoing the early stages of apoptosis. For the examination of Golgi tendon organs, muscles denervated at P4 were examined at P5 and P6. TUNEL-labeled, S-100-positive cells were rarely observed in intact tendon organs at this age (Fig. 2A). However, TUNEL-labeled nuclei were clearly evident in each tendon organ after denervation and were often located within S-100-positive cells (Fig. $2 B$ ). In these cases, anti-S-100 failed to label the Schwann cell nucleus, and the cytoplasm appeared to condense around the nucleus (Fig. 2C). These are morphological signs of apoptosis (Wyllie, 1987; Sen, 1992). In some cases the Schwann cells appeared to fragment into S-100-positive and TUNEL-positive pieces that may be apoptotic bodies (Kerr et al., 1972).

The number of tendon organs and the number of apoptotic Schwann cells per tendon organ were counted at P5 and P6 in control muscles and muscles denervated by sciatic nerve axotomy at P4 (Table 1). The number of structures in the tendonous regions of the muscles identifiable as Golgi tendon organs did not decrease dramatically over controls by $2 \mathrm{~d}$ after denervation; however, the number of apoptotic cells per tendon organ was increased. Furthermore, the overall morphology of tendon organs in the denervated muscles at P6 was also different than that of controls. Denervated tendon organs had a dispersed structure (as revealed by anti-S-100 labeling), many Schwann cells appeared fragmented, and there were qualitatively fewer Schwann cells per 
Table 1. Number of Golgi tendon organs and number of apoptotic cells per Golgi tendon organ in normal soleus muscles and muscles denervated at $\mathrm{P4}$ and examined at P5-P7

\begin{tabular}{|c|c|c|c|c|c|}
\hline & $\begin{array}{l}\text { P5 } \\
\text { GTO }\end{array}$ & $\begin{array}{l}\text { P5 } \\
\text { Apo cells }\end{array}$ & $\begin{array}{l}\text { P6 } \\
\text { GTO }\end{array}$ & $\begin{array}{l}\text { P6 } \\
\text { Apo cells }{ }^{a}\end{array}$ & $\begin{array}{l}\text { P7 } \\
\text { GTO }\end{array}$ \\
\hline Control & $\begin{array}{l}15.0 \pm 0.7 \\
(n=9)\end{array}$ & $\begin{array}{l}0.2 \pm 1.9 \\
(n=9)\end{array}$ & $\begin{array}{l}14.7 \pm 1.4 \\
(n=7)\end{array}$ & $\begin{array}{l}0.3 \pm 0.6 \\
(n=7)\end{array}$ & $\begin{array}{l}14.3 \pm 1.0 \\
(n=5)\end{array}$ \\
\hline Den at P4 & $\begin{array}{l}14.3 \pm 0.7 \\
(n=8)\end{array}$ & $\begin{array}{l}5.2 \pm 2.2 \\
(n=8)\end{array}$ & $\begin{array}{l}13.8 \pm 1.7 \\
(n=4)\end{array}$ & $\begin{array}{l}8.0 \pm 3.3 \\
(n=4)\end{array}$ & $\begin{array}{c}0 \\
(n=5)\end{array}$ \\
\hline
\end{tabular}

GTO, Golgi tendon organ; Apo, apoptotic; Den, denervated.

${ }^{a}$ Number of apoptotic cells per GTO was counted for each Golgi tendon organ in the muscle.

Table 2. Number of Pacinian corpuscles and number of apoptotic cells per Pacinian corpuscle in normal interosseus membranes and membranes denervated at $\mathrm{P2}$ and examined at $\mathrm{P5}$ and $\mathrm{P6}$

\begin{tabular}{llll} 
& P5 & P5 & P6 \\
& PC & Apo cells $^{a}$ & PC \\
\hline Control & $47.3 \pm 4.3$ & $0.9 \pm 0.8$ & $50.0 \pm 2.1$ \\
& $\begin{array}{l}(n=11) \\
\text { Den at P2 }\end{array}$ & $\begin{array}{l}(n=11) \\
(n=5)\end{array}$ & $\begin{array}{l}5.2 \pm 3.1 \\
(n=5)\end{array}$ \\
& $(n=6)$ & $(n=6)$
\end{tabular}

PC, Pacinian corpuscle; Apo, apoptotic; Den, denervated.

${ }^{a}$ Number of apoptotic cells per PC was counted in 20 corpuscles per preparation.

tendon organ, suggesting that a number of cells had already died, and their debris had been removed. The TUNEL method labels cells in the earliest stages of DNA fragmentation, and fragmentation can be absent at certain stages of apoptosis (Cohen et al., 1992), so TUNEL at any one time point underestimates the extent of apoptosis.

Whole mounts of interosseus nerves and membranes containing intact Pacinian corpuscles or Pacinian corpuscles denervated at P2 were examined using labeling techniques similar to those described above. Preparations double labeled for S-100 and TUNEL were examined at P5, $1 \mathrm{~d}$ earlier than the disappearance of these mechanoreceptors after denervation at P2. The number of apoptotic Schwann cells was counted in 20 corpuscles per preparation. Innervated corpuscles had few apoptotic Schwann (inner core) cells (Fig. 2D); however, there were many in the denervated preparations (Fig. $2 E$ ). Control membranes with intact interosseus nerves had $\sim 47$ corpuscles with one apoptotic cell per corpuscle; however, denervated preparations had approximately one-half the number of corpuscles $(\sim 24)$ and a 5-fold increase in the number of apoptotic cells per corpuscle (Table 2). Additionally, at P5 after denervation at P2, 10 corpuscle-like structures were located adjacent to the interosseus nerve and in the region of other corpuscles that had only two to four brightly labeled and clustered S-100-positive cells. All of the Pacinian corpuscles remaining in denervated membranes were smaller than control corpuscles, and many had S-100-positive cells that appeared only very loosely compacted (Fig. $2 F$ ). Some Schwann cells associated with the preterminal axon were also seen to be apoptotic, but this was not systematically examined. Many of the double-labeled cells were on the outer aspect of the S-100positive inner core, suggesting that these were actually inner core cells rather than Schwann cells that contributed to the developing myelin sheath of the sensory axon. In addition, confocal images taken through the inner core region identified these cells as apoptotic (not shown).

\section{Glial growth factor prevents denervation-induced Schwann cell apoptosis}

Terminal Schwann cells at the developing neuromuscular junction and premyelinating Schwann cells associated with developing motor nerves seem to be trophically dependent on motor axonderived neuregulin (Grinspan et al., 1996; Trachtenberg and Thompson, 1996). We investigated whether Schwann cells associated with mechanoreceptive afferents may also be trophically dependent on neuregulin by applying recombinant human GGF2 in an attempt to rescue mechanoreceptor-associated Schwann cells from denervation-induced apoptosis.

For an examination of Golgi tendon organs, a BSA-containing vehicle solution with or without GGF2 was injected subcutaneously for 1-2 $\mathrm{d}$ into the hindlimbs of animals denervated at P4. Innervated, noninjected muscles contralateral to the GGFtreated muscles were used as controls, because preliminary experiments showed that GGF2 does not seem to have systemic effects in a contralateral hindlimb when injected into the other limb (i.e., the number of tendon organs in a normally innervated soleus located contralateral to a denervated soleus treated with or without GGF2 is the same as the number of tendon organs in a soleus of an untreated littermate) (data not shown). Preparations were double-labeled with anti-S-100 and TUNEL and examined at P5 and P6. GGF2 rescued the Schwann cells in tendon organs from denervation-induced apoptosis (Fig. $3 A, B$ ). A summary of quantitative data is presented in Figure 5. At P5 and P6, control soleus muscles, denervated muscles treated with vehicle, and denervated muscles treated with GGF2 all had similar numbers of tendon organs (13-15). However, the denervated muscles receiving vehicle had many more apoptotic cells per tendon organ than did the denervated muscles receiving GGF2. In fact, the numbers of apoptotic cells in the denervated, GGF2-treated muscles were similar to those of contralateral control muscles.

Similar to Golgi tendon organs, GGF2 rescued the Schwann, or inner core, cells of denervated Pacinian corpuscles (Figs. 3C,D, 5). Pacinian corpuscles denervated at $P 2$ were given GGF2 for $3 \mathrm{~d}$ and examined at P5, a time when previous examinations revealed that their normal complement of corpuscles is greatly reduced, and all of the remaining corpuscles are small and dispersed in morphology compared with controls (see above). Preparations were labeled with anti-S-100 and the TUNEL method. Denervated animals treated with vehicle alone had many fewer Pacinian corpuscles compared with denervated, GGF2-treated animals or controls. Furthermore, the number of apoptotic cells per receptor was much higher in the denervated preparations that received vehicle compared with denervated GGF2-treated animals or controls.

The effect of GGF2 administration was also examined on Golgi tendon organs and Pacinian corpuscles at a time after denerva- 

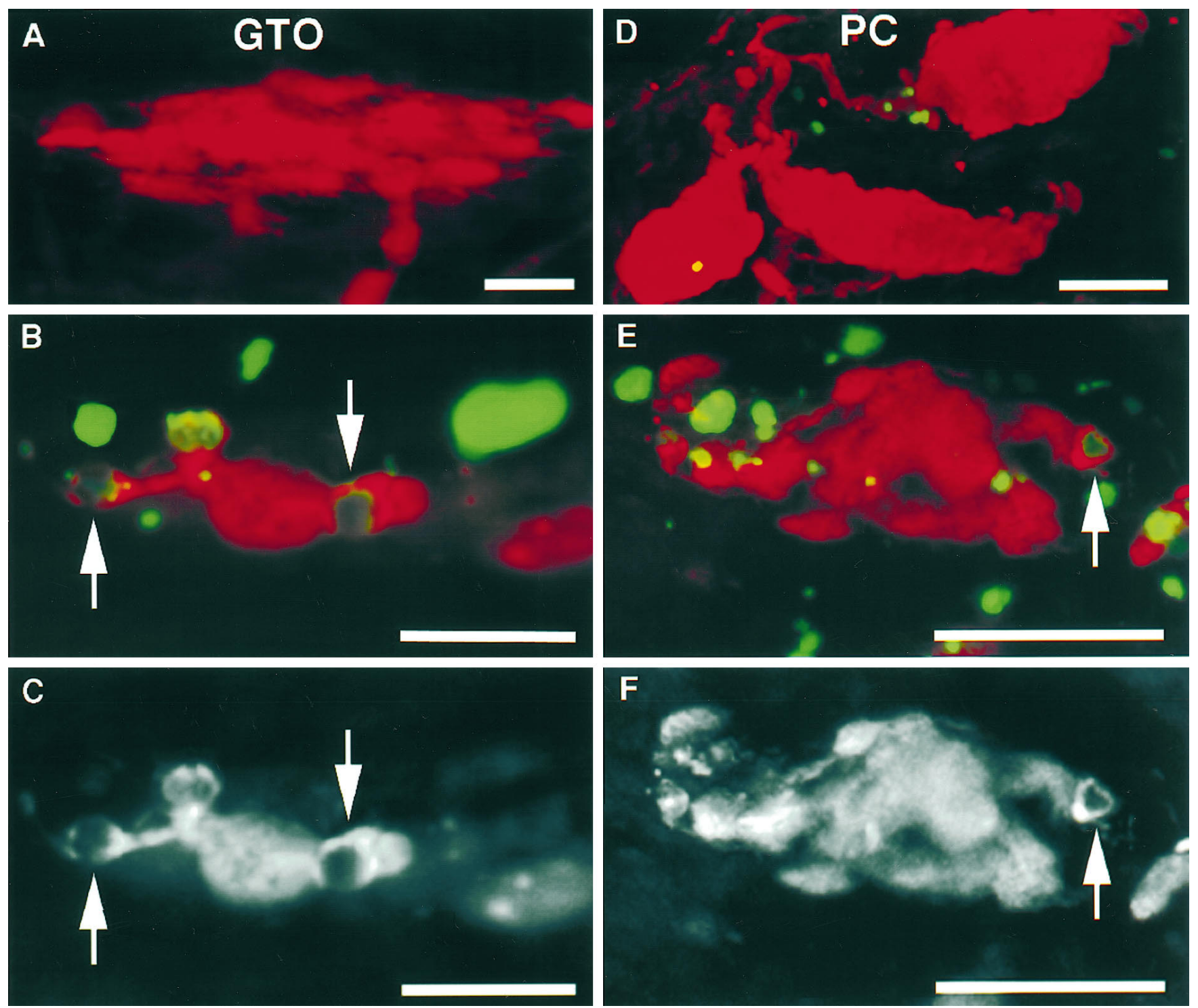

Figure 2. Schwann cells of Golgi tendon organs $(G T O ; A-C)$ and Pacinian corpuscles $(P C ; D-F)$ undergo apoptosis after denervation. All preparations were double-labeled with anti-S-100 for Schwann cells $($ red $)$ and the TUNEL technique for apoptotic nuclei $($ green $)$. $D-F$ are confocal images. $A$, $D$, Control tendon organ at P6 and control Pacinian corpuscles at P5, respectively. No apoptotic cells are seen in the tendon organ; a few apoptotic cells are present in the corpuscles. $B, E$, $\mathrm{P} 6$ tendon organ denervated at $\mathrm{P} 4$ and $\mathrm{P} 5$ Pacinian corpuscle denervated at $\mathrm{P} 2$, respectively. Apoptotic cells are clearly evident, and both mechanoreceptors appear to have fewer Schwann cells than controls. Although some TUNEL-positive nuclei co-localize with S-100-positive Schwann cells, others do not. Some of the latter may be apoptotic Schwann cells that have already lost their S-100 immunoreactivity. $C$, $F$, Black-and-white images of only the S-100 label from $B, E$, respectively. Note S-100-negative nuclei of apoptotic cells. Arrows identify the same apoptotic cells in $B, C$ for the tendon organ and in $E, F$ for the Pacinian corpuscle. Scale bars: $A-C, 20 \mu \mathrm{m} ; D-F, 30 \mu \mathrm{m}$.

tion when, in the absence of GGF2, all of these structures have disappeared. By late P7, when all tendon organs have normally disappeared after denervation at P4, labeling with S-100 revealed that all tendon organs were preserved (as identified by staining for their Schwann cells) after the exogenous administration of GGF2 (Figs. 4A, 5). The morphology of these structures looked strikingly normal. Similar to tendon organs, by late P6 when Pacinian corpuscles have normally disappeared after denervation at P2, S-100 labeling revealed that Pacinian corpuscles remained in animals receiving GGF2 during this time (Figs. 4B, 5). All denervated Pacinian corpuscles that were preserved by GGF were smaller than age-matched controls. Although approximately onefourth of these Pacinian corpuscles appeared elongated in morphology (similar to age-matched controls), most were rounder.
For Golgi tendon organs and Pacinian corpuscles, double-labeling with antibodies to Schwann cells and neurofilament and synaptophysin confirmed that none of the rescued Schwann cells were associated with axons (data not shown).

\section{Axons and Schwann cells associated with mechanoreceptors are immunoreactive for neuregulin and neuregulin receptors, respectively}

If a neuregulin such as GGF2 is an axon-derived trophic factor that functions in vivo to maintain directly the Schwann cells associated with mechanosensory end organs, then the sensory nerve terminals should contain neuregulin protein, and the Schwann cells should express the appropriate neuregulin receptors. Antibodies to neuregulin and the three neuregulin receptors 

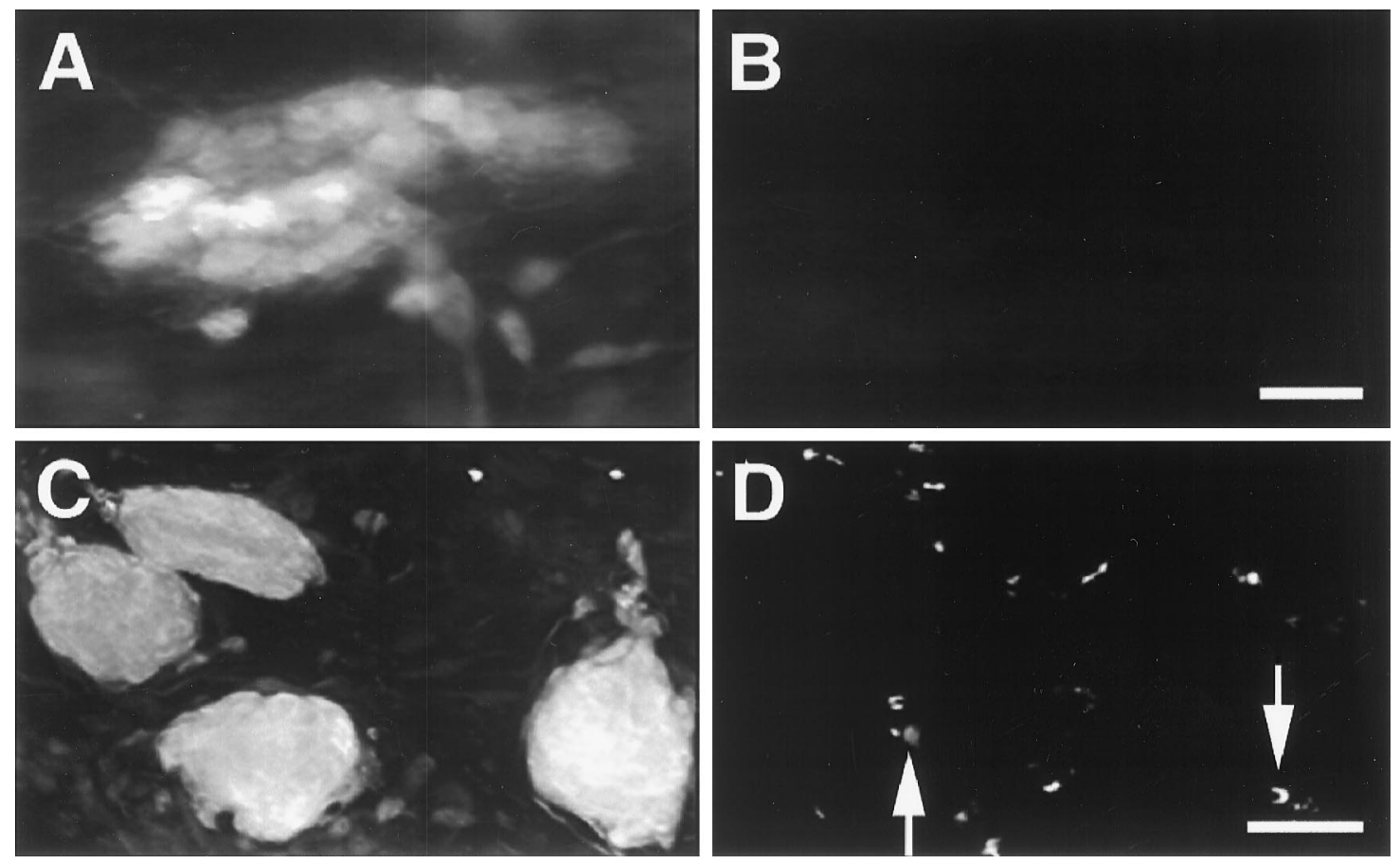

Figure 3. GGF2 rescues mechanoreceptor Schwann cells from denervation-induced apoptosis. $A$, $C$, Anti-S-100 labels; $B, D$, TUNEL labels. $C$, $D$, Confocal images; $A, B$, P6 Golgi tendon organ that was denervated at P4 and received GGF2 for 2 d. There are no TUNEL-positive Schwann cells (compare with Fig. 2B). C, D, P5 Pacinian corpuscles that were denervated at P2 and received GGF2 for 3 d. There are fewer TUNEL-positive cells (arrows in $D$ ) in these corpuscles than preparations that did not receive GGF2 (compare with Fig. 2E). The two corpuscles at the top left have no apoptotic cells, a result that was never seen in denervated corpuscles that did not receive GGF2. In addition, some corpuscles that received growth factor were rounder than normal corpuscles at this age (compare with Fig. $1 C$ ). Scale bars: in $B, 50 \mu \mathrm{m}$ for $A, B$; in $D, 50 \mu \mathrm{m}$ for $C, D$.

erbB2, erbB3, and erbB4 were used to examine this possibility. Whole mounts of Golgi tendon organs and Pacinian corpuscles at P5 were labeled with anti-S-100 to identify Schwann cells, antierbB3 to localize this receptor, and anti-synaptophysin to identify the nerve terminal. In whole mounts, Schwann cells of both types of mechanoreceptors were immunopositive for erbB3 (Fig. 6 for Pacinian corpuscles; Golgi tendon organ not shown). The erbB3 staining appeared absent from the nucleus of inner core Schwann cells. Confocal images revealed that there was often a high immunoreactivity for erbB3 surrounding the nerve terminal (i.e., in the Schwann cells wrapping the axon as it entered the corpuscle) (data not shown). The specificity of erbB3 immunostaining was confirmed by its elimination after preincubation of the erbB3 antibody with the peptide it was raised against.

Whole-mount preparations of P5 Pacinian corpuscles and Golgi tendon organs did not stain for erbB2, erbB4, or neuregulin; however, each of these probes revealed positive immunoreactivity in cryostat sections made of Pacinian corpuscles in interosseus membranes (Fig. 7). In sections, the inner core region of Pacinian corpuscles stained with anti-S-100 (Fig. 7A), anti-erbB2 (Fig. 7B), anti-erbB3 (result not shown), and anti-erbB4 (Fig. 7C). The specificity of staining for each antibody was confirmed by its elimination after incubation with the appropriate control peptide. Interestingly, erbB4 has not been detected in Schwann cells that are not associated with mechanoreceptors (Grinspan et al., 1996; Carroll et al., 1997), except in one recent study (Vartanian et al., 1997) in which trace amounts of erbB4 were detected in cultured rat Schwann cells by Western blotting. In addition, message to erbB4 was detected in human Schwann cells (Levi et al., 1995). Finally, Pacinian corpuscles were repeatedly identifiable by Nomarski optics (Fig. 7D), and their sensory nerve terminal could be double-labeled with antibodies to synaptophysin (Fig. 7E) as well as neuregulin (Fig. $7 F$ ).

\section{DISCUSSION}

Our experiments show that Schwann cells associated with the sensory endings of developing Golgi tendon organs and Pacinian corpuscles die via apoptosis after sciatic nerve axotomy. This axotomy-induced cell death can be prevented by exogenous administration of the neuregulin GGF2. Schwann cells of mechanoreceptors are immunopositive for neuregulin receptors, and the sensory nerve terminal is immunopositive for neuregulin. Because Schwann cell apoptosis is correlated with the inability of these mechanoreceptors to reform after neonatal denervation, this study suggests that axon-derived neuregulins acting via Schwann cells are important factors in the development and maintenance of peripheral sensory end organs.

The concept of a neural influence on the development of sensory receptors originated with studies on the development and maintenance of taste buds and lateral line organs (Parker, 1932; Torrey, 1934). A number of subsequent reviews have concluded that the trophic dependence of the non-neural components of many peripheral sense organs is ultimately derived from neurons (e.g., Zelená, 1964; Guth, 1971). Good evidence in support of this hypothesis comes from studies such as that of Sloan et al. (1983), which showed that blocking axonal transport results in the elimination of taste receptors. However, the identity of many of these trophic factors, their sources, the mechanisms by which such substances are released, and the cells that they might act on are incompletely characterized.

One of the best candidate neurotrophic factors for mechanoreceptors has been neurotrophin-3 (NT-3). Homozygous NT-3- 

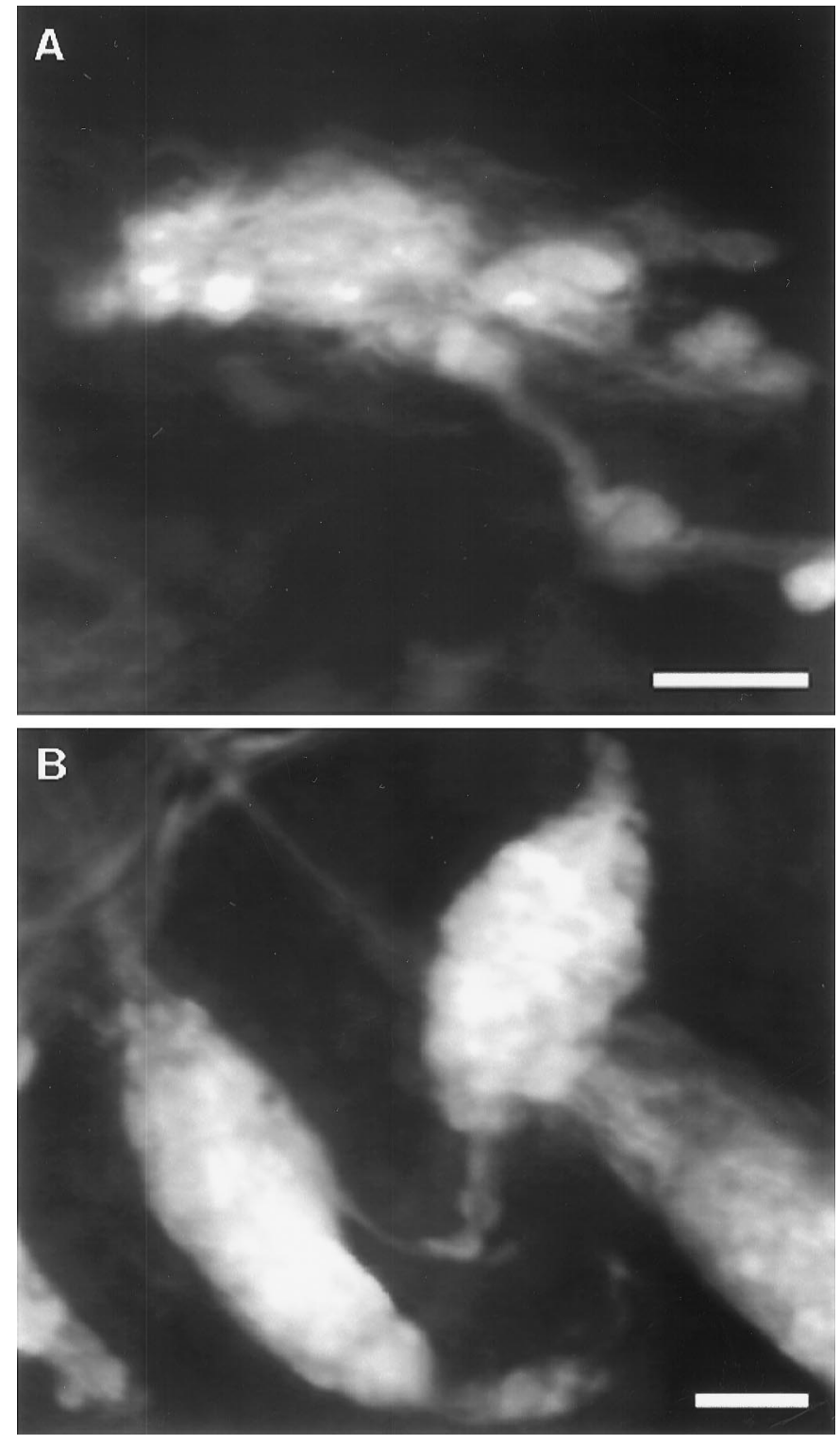

Figure 4. GGF2 rescues the Schwann cells of mechanoreceptors at a time after denervation when normally these mechanoreceptors have disappeared. End organs in both panels were labeled with an antibody to S-100. A, Schwann cells in a P7 Golgi tendon organ denervated at P4 and given GGF2 for 3 d. $B$, Schwann cells in a P6 Pacinian corpuscle denervated at P2 and given GGF2 for $4 \mathrm{~d}$. The Schwann cells of these two rescued corpuscles are elongated, similar to age-matched controls; however, many corpuscles that were denervated and received GGF2 were rounder in morphology. In addition, a consistent finding was that Schwann cells of both types of mechanoreceptors that received GGF2 for this longer period appeared less distinct and often extended small processes. Some preparations were labeled with antibodies to S-100 and neurofilament and synaptophysin, and none of the rescued Schwann cells was associated with axons (results not shown). Scale bars: $A, 20 \mu \mathrm{m} ; B, 20 \mu \mathrm{m}$.

deficient mice are void of Golgi tendon organs and another peripheral receptor, muscle spindles, whereas heterozygous mutants have only one-half their normal number of spindles (Ernfors et al., 1994). Studies suggest that NT-3 seems to regulate the number of mechanoreceptors in these mice indirectly by supporting the survival of the appropriate classes of sensory neurons (Ernfors et al., 1994). Interestingly, although NT-3 might be vital to the development of at least some mechanoreceptors via its
A

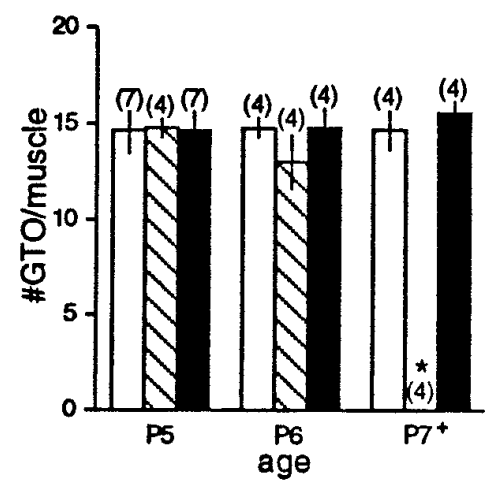

C

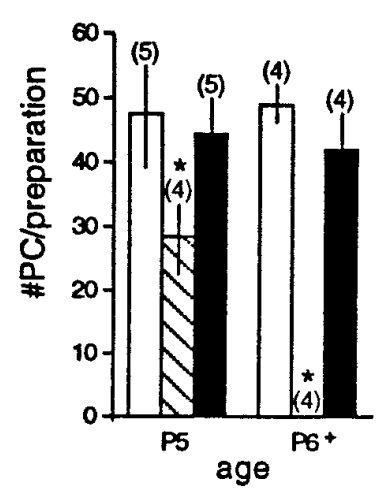

B

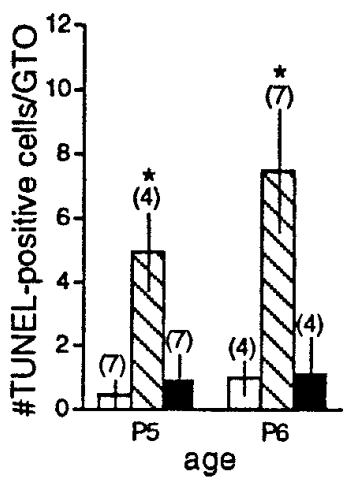

D

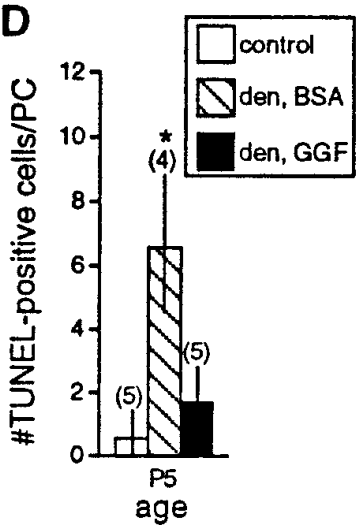

Figure 5. Quantitative assessment of the rescue of mechanoreceptor Schwann cells by GGF2. $A, B, \mathrm{GGF} 2$ rescues the Schwann cells of denervated Golgi tendon organs $(G T O)$ from apoptosis. Animals were denervated at P4 and examined at P5-P7. The number of GTOs per muscle is based on S-100 immunostaining. Denervated animals either received a BSA-containing vehicle solution without GGF2 (den, $B S A)$ or with GGF2 (den, $G G F)$. Innervated, noninjected muscles contralateral to the GGF-treated muscles were used as controls. $C, D, \mathrm{GGF} 2$ rescues the Schwann (inner core) cells of denervated Pacinian corpuscles $(P C)$ from apoptosis. Receptors were counted as described above. Animals were denervated at P2 and examined at P5 or P6. All groups were doublelabeled with anti-S-100 and TUNEL, except those marked + , which were labeled only with anti-S-100. The number in parentheses above each bar indicates the number of preparations examined. Error bars indicate SD. *Denervated groups that were significantly different from both the agematched control and GGF2-treated groups (Student's $t$ test, $p<0.05$ ).

survival effects on sensory neurons, the complement of Pacinian corpuscles in these NT-3-deficient mice seemed qualitatively unaffected (Ernfors et al., 1994), suggesting that other factors play a role in mechanoreceptor development and survival. Two other candidate trophic substances for mechanoreceptors include calcitonin gene-related peptide and fibroblast growth factor, both of which are found in nerve terminals of afferents associated with mechanoreceptors (Strasmann et al., 1990; Desaki et al., 1992). These previous results have left unanswered the question of which, if any, sensory neuron-derived factors support the survival of the non-neural components of the mechanoreceptors themselves.

Our study identifies GGF2, or a neuregulin like GGF2, as a putative trophic substance for mechanoreceptor development. Glial growth factor 2 (Marchionni et al., 1993) is a member of the neuregulin family of proteins that includes heregulin (Holmes et al., 1992); Neu differentiation factor (Wen et al., 1992); the protein purified for its acetylcholine receptor inducing activity, 

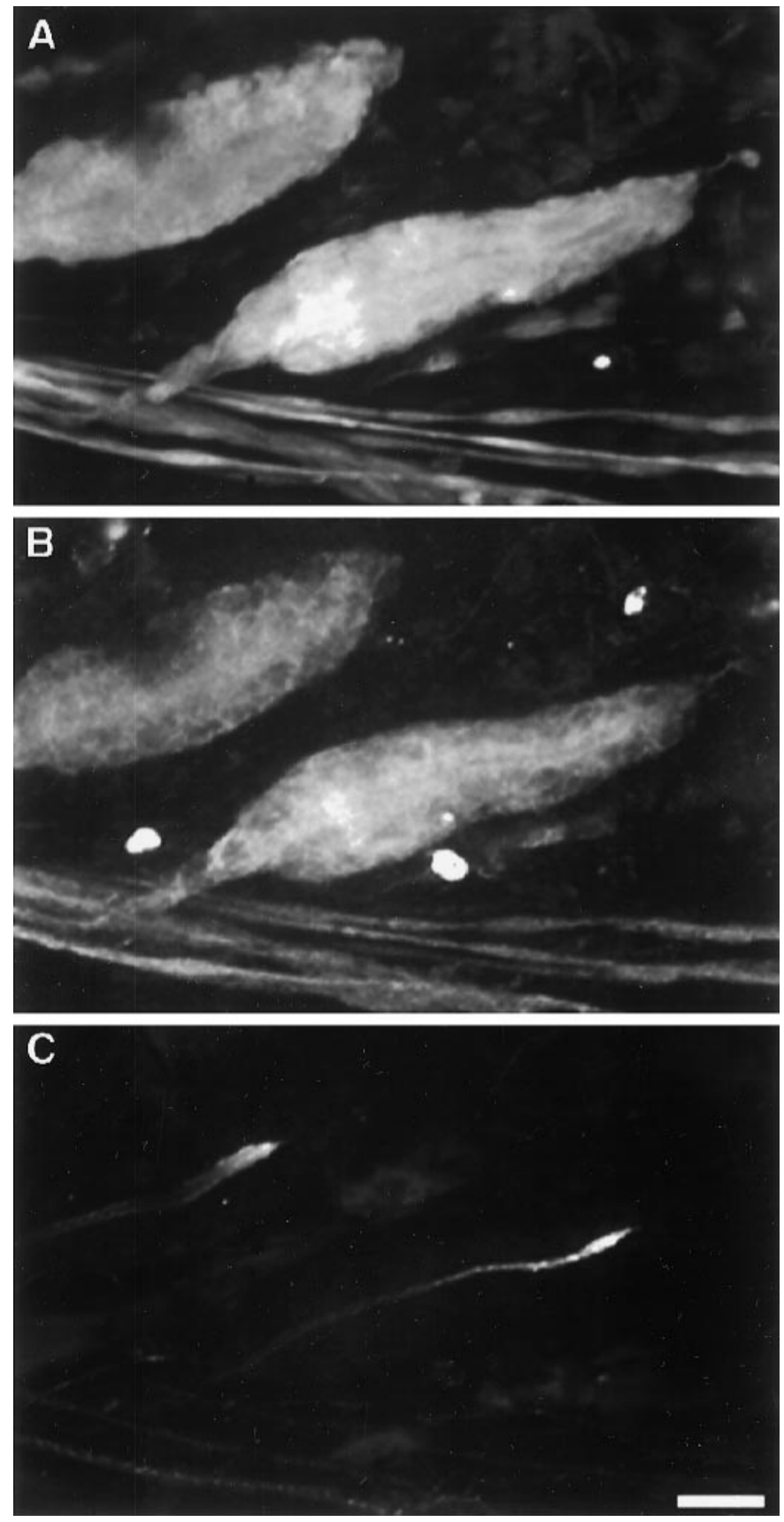

Figure 6. Schwann cells associated with Pacinian corpuscles are immunopositive for the neuregulin receptor erbB3. $A-C$, Confocal images of a whole mount of P5 Pacinian corpuscles triple-labeled with anti-S-100 for Schwann cells $(A)$, anti-erbB3 $(B)$, and anti-synaptophysin to show the nerve terminal $(C)$. ErbB3 immunoreactivity co-localizes with Schwann cells. Because the antibodies to S-100 and erbB3 are both rabbit polyclonals, the tissue was stained using the technique of dilutional neglect for these two antibodies (see Materials and Methods). Scale bar, $20 \mu \mathrm{m}$.

ARIA (Falls et al., 1993); and sensory and motor neuron derivedfactor (SMDF) (Ho et al., 1995). All of these molecules are products of a single gene that encodes multiple alternatively spliced mRNAs, are indirect ligands for the erbB2 p185 receptor tyrosine kinase, and share an EGF-like domain important for their biological activity (for review, see Lemke, 1996). The presence of multiple isoforms of each of these factors suggests a great diversity, as well as potential overlap, in their biological functions.
Previous studies have shown that neuregulins are present in sensory and motor axons during early development, suggesting that they might act as trophic factors for organization of the peripheral nervous system. For example, GGF2 mRNA has been localized to motor neurons as well as primary sensory neurons as early as embryonic day 11 in mouse embryos (Marchionni et al., 1993). SMDF, however, has recently been suggested to be the predominant neuregulin isoform expressed in sensory neurons. In situ hybridizations show that SMDF mRNA is strongly expressed throughout the entire embryonic dorsal root ganglia, whereas GGF is only expressed in a subset of these neurons (Ho et al., 1995). In addition to the appropriate spatial and temporal distribution of neuregulins during development, there is now good experimental evidence that neuregulins are important factors for the survival of Schwann cells associated with peripheral axons. Neuregulins can prevent apoptosis of Schwann cell precursors in vitro (Dong et al., 1995) and denervation-induced apoptosis of terminal Schwann cells in vivo (Trachtenberg and Thompson, 1996). Most recently, it has been suggested that the number of premyelinating Schwann cells in neonatal rat sciatic nerve is regulated by axon-derived neuregulin (Grinspan et al., 1996). Thus, the results presented here add to the growing body of evidence suggesting that neuregulins are trophic factors for developing Schwann cells.

Neuregulin receptors erbB2, erbB3, and erbB4 are members of the EGF receptor family (Bargmann et al., 1986; Kraus et al., 1989; Plowman et al., 1990, 1993). Interactions between neuregulin and the erbB receptors themselves have proven quite intricate and complex, and it is suggested that different combinations of receptors generate diversity in cell signaling (Carraway and Cantley, 1994). For example, GGF2 can stimulate phosphorylation of erbB2 and erbB3; however, it can only act as a direct ligand for erbB3 and erbB4. ErbB3 can signal only through its association with one of the other erbB receptors or another member of the EGF receptor family, yet cell signaling through erbB4 can occur via either its homodimerization or its interaction with one of the other erbB receptors. Up until the present study, there was no evidence of the expression of neuregulin receptors by the nonmyelinating Schwann cells associated with mechanoreceptors; however, nonmyelinating Schwann cells of the developing nerve have been shown to express both erbB2 and erbB3 receptors (Grinspan et al., 1996). The expression of erbB2, erbB3, and erbB4 receptors by Schwann cells associated with Golgi tendon organs and Pacinian corpuscles, as well as the presence of neuregulin in the sensory nerve terminals of these mechanoreceptors, strengthen the hypothesis that neuregulins play an important role in the development of mechanosensory end organs.

Sensory axons seem to provide trophic factors (such as neuregulin) that normally support the survival of Schwann cells associated with developing mechanoreceptors. It is likely that Schwann cells reciprocally provide trophic factors for the sensory axons. Good evidence for a trophic interdependence comes from recent experiments by Verdi et al. (1996) that suggest a reciprocal cell-cell interaction between neuronal precursors and their surrounding non-neuronal cells is mediated by neurotrophins and neuregulins. These experiments showed that NT-3, which supports the survival and differentiation of some sympathetic neuroblasts in vitro, is produced by non-neuronal cells, which neighbor the neuroblasts in vivo. In turn, NT-3 production in these nonneuronal cells is regulated by soluble factors derived from the neuroblasts (including a neuregulin). These results are interesting with respect to the results mentioned above that in early devel- 

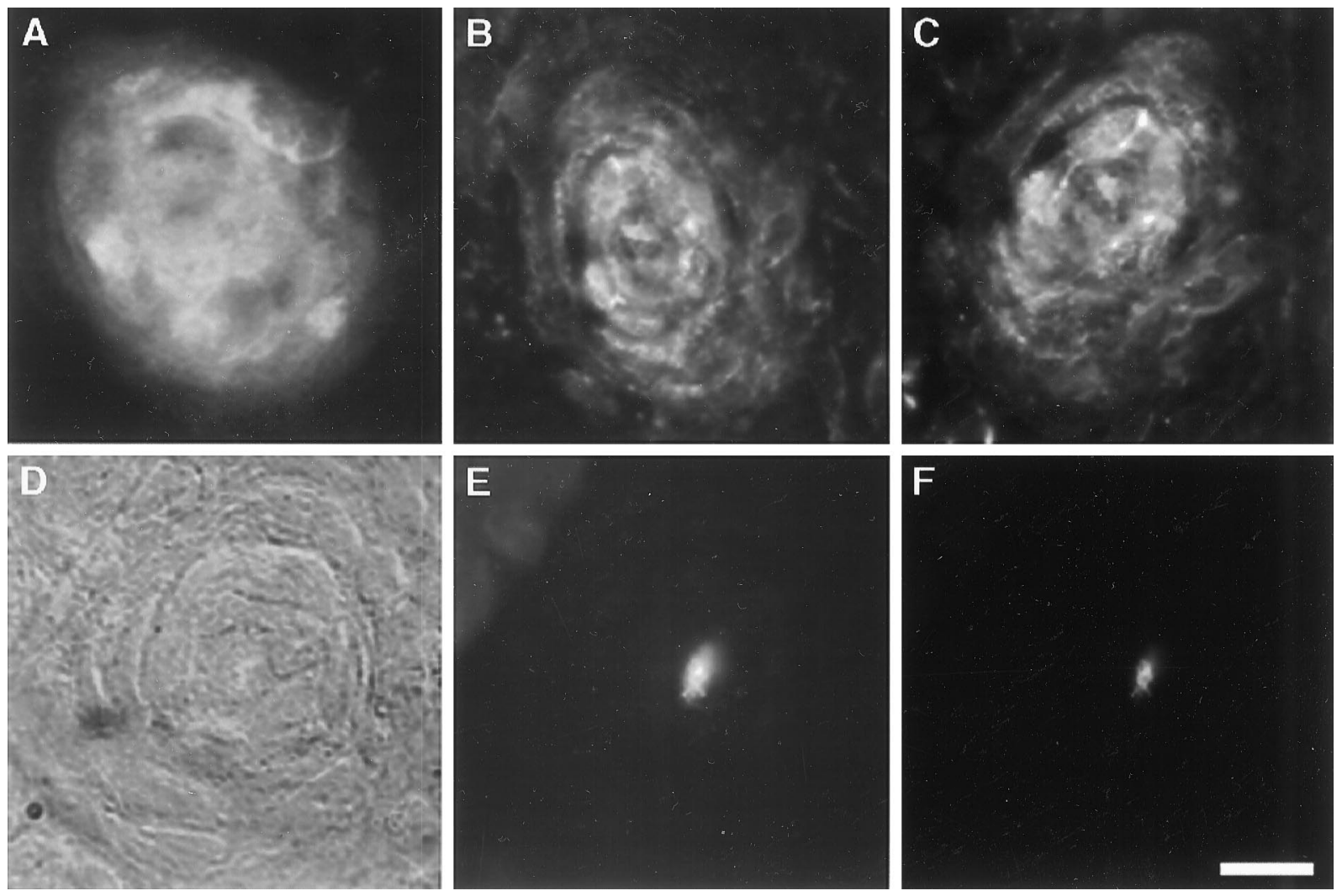

Figure 7. Schwann cells associated with Pacinian corpuscles are immunopositive for the neuregulin receptors erbB2 and erbB4, and sensory axon terminals are immunopositive for neuregulin. All panels show cryostat cross-sections of P5 Pacinian corpuscles. $A-C$, Images of different corpuscles labeled with anti-S-100 $(A)$, anti-erbB2 $(B)$, and anti-erbB4 $(C)$. Sections of Pacinian corpuscles also stained with anti-erbB3 (results not shown). Because these preparations were unfixed for sectioning, S-100, a soluble protein, is less distinctly localized to Schwann cells than in other preparations (for example, see Fig. 1). The erbB4 antibody used here was anti-erbB4 (RB-284-P; Neomarkers, Inc.); affinity-purified antibody 616 (kindly provided by Dr. C. Lai) was also used and gave similar results. $D-F$, Nomarski and immunofluorescent images of the same corpuscle. The Nomarski image identifies the corpuscle $(D)$, and the centrally located nerve terminal is double-labeled with antibodies to synaptophysin $(E)$ and neuregulin $(F)$. Scale bar, $20 \mu \mathrm{m}$.

opment NT-3 seems to regulate the number of some types of mechanoreceptors indirectly by supporting the survival of the appropriate classes of sensory neurons (Ernfors et al., 1994).

These neuronal-non-neuronal trophic interactions may be a common theme during development of the peripheral nervous system. Based on our finding that sensory axon-derived neuregulin supports the survival of Schwann cells associated with developing mechanoreceptors and evidence by others that Schwann cells produce a variety of trophic factors (Reynolds and Woolf, 1993), we suggest that Schwann cells at mechanoreceptive terminal endings supply substances that are important for keeping sensory neurons alive during mechanoreceptor maturation. The apoptotic death and subsequent disappearance of the Schwann cells associated with these mechanoreceptors after neonatal denervation, and therefore a lack of supply of Schwann cell-derived substances, may partially explain why reinnervation of these structures is so poor.

\section{REFERENCES}

Astrow SH, Son YJ, Thompson WJ (1994) Differential neural regulation of a neuromuscular junction-associated antigen in muscle fibers and Schwann cells. J Neurobiol 25:937-952.

Bargmann CI, Hung MC, Weinberg RA (1986) The neu oncogene encodes an epidermal growth factor receptor-related protein. Nature 319:226-230.

Barker D (1974) The morphology of muscle receptors. In: Handbook of sensory physiology, III. Muscle receptors (Hunt CC, ed), pp 2-190. Berlin: Springer.
Carraway III KL, Cantley LC (1994) A neu acquaintance for erbB3 and erbB4: a role for receptor heterodimerization in growth signaling. Cell 78:5-8.

Carroll SL, Miller ML, Frohnert PW, Kim SS, Corbett JA (1997) Expression of neuregulins and their putative receptors, ErbB2 and ErbB3, is induced during Wallerian degeneration. J Neurosci 17:1642-1659.

Cohen GM, Sun XM, Snowden RT, Dinsdale D, Skilleter DN (1992) Key morphological features of apoptosis may occur in the absence of internucleosomal DNA fragmentation. Biochem J 286:331-334.

De Camilli P, Vitadello M, Canevini MP, Zanoni R, Jahn R, Gorio A (1988) The synaptic vesicle proteins synapsin I and synaptophysin (protein P38) are concentrated both in efferent and afferent nerve endings of the skeletal muscle. J Neurosci 8:1625-1631.

Desaki J, Matsuda S, Okumura N, Koyama Y, Sakanaka M (1992) Fine structure of nerve processes containing basic fibroblast growth factor in muscle spindles of the rat masseter muscle. Neurosi Lett 137:237-240.

Dong Z, Brennan A, Liu N, Yarden Y, Lefkowitz G, Mirsky R, Jessen KR (1995) Neu differentiation factor is a neuron-glia signal and regulates survival, proliferation, and maturation of rat Schwann cell precursors. Neuron 15:585-596.

Ernfors P, Lee K-F, Kucera J, Jaenisch R (1994) Lack of neurotrophin-3 leads to deficiencies in the peripheral nervous system and loss of limb proprioceptive afferents. Cell 77:503-512.

Falls DL, Rosen KM, Corfas G, Lane WS, Fishbach GD (1993) ARIA, a protein that stimulates acetylcholine receptor synthesis, is a member of the neu ligand family. Cell 72:801-815.

Grinspan JB, Marchionni MA, Reeves M, Coulaloglou M, Scherer SS (1996) Axonal interactions regulate Schwann cell apoptosis in developing peripheral nerve: neuregulin receptors and the role of neuregulins. J Neurosci 16:6107-6118.

Guth L (1971) Degeneration and regeneration of taste buds. In: Hand- 
book of sensory physiology, IV. Chemical senses (Beidler LM, ed), pp 63-74. Berlin: Springer.

Ho WH, Armanini MP, Nuijens A, Phillips HS, Osheroff PL (1995) Sensory and motor neuron-derived factor: a novel heregulin variant highly expressed in sensory and motor neurons. J Biol Chem 270:14523-14532.

Holmes WE, Sliwkowski MX, Akita RW, Henzel WJ, Lee J, Park JW, Yansura D, Ababi NA, Raab H, Lewis GD, Shepard HM, Kuang WJ, Wood WI, Goeddel DV, Vandlen RL (1992) Identification of heregulin, a specific activator of p185erbB2. Science 256:1205-1210.

Iwanaga T, Fujita T, Takahashi Y, Nakajima T (1982) Meissner's and Pacinian corpuscles as studied by immunohistochemistry for S-100 protein, neuron-specific enolase and neurofilament protein. Neurosci Lett 31:117-121.

Jami L (1992) Golgi tendon organs in mammalian skeletal muscle: functional properties and central actions. Physiol Rev 72:623-666.

Kerr JFR, Wyllie AH, Currie AR (1972) Apoptosis: a basic phenomenon with wide ranging implications in tissue kinetics. $\mathrm{Br} \mathbf{J}$ Cancer 26:239-257.

Kraus MH, Issing W, Miki T, Popescu NC, Aaronson SA (1989) Isolation and characterization of ERBB3, a third member of the ERBB/ epidermal growth factor receptor family: evidence for overexpression in a subset of human mammary tumors. Proc Natl Acad Sci USA 86:9193-9197.

Lemke G (1996) Neuregulins in development. Mol Cell Neurosci 7:247-262.

Levi ADO, Bunge RP, Lofgren JA, Meima JA, Hefti F, Nikolics K, Sliwkowski NX (1995) The influence of heregulins on human Schwann cell proliferation. J Neurosci 15:1329-1340.

Marchionni MA, Goodearl ADJ, Chen MS, Bermingham-McDonogh O, Kirk C, Hendricks M, Danehy F, Misumi D, Sudhalter J, Kobayashi K, Wroblewski D, Lynch C, Baldassare M, Hiles I, Davis JB, Hsuan JJ, Totty NF, Otsu M, McBurney RN, Waterfield MD, Stroobant P, Gwynne D (1993) Glial growth factors are alternatively spliced erbB2 ligands expressed in the nervous system. Nature 362:312-318.

Munger BL, Ide C (1987) The enigma of sensitivity in Pacinian corpuscles: a critical review and hypothesis of mechano-electric transduction. Neurosci Res 5:1-15.

Parker GH (1932) On the trophic impulse so-called, its rate and nature. Am Nat 66:147-158.

Plowman GD, Whitney GS, Shoyab M (1990) Molecular cloning and expression of an additional epidermal growth factor receptor-related gene. Proc Natl Acad Sci USA 87:4905-4909.

Plowman GD, Culouscou JM, Whitney GS, Green JM, Carlton GW, Foy L, Neubauer MG, Shoyab M (1993) Ligand-specific activation of HER4/p180erbB4, a fourth member of the epidermal growth factor receptor family. Proc Natl Acad Sci USA 90:1746-1750.

Reynolds ML, Woolf CJ (1992) Terminal Schwann cells elaborate extensive processes following denervation of the motor endplate. J Neurocytol 21:50-66.

Reynolds ML, Woolf CJ (1993) Reciprocal Schwann cell-axon interactions. Curr Opin Neurobiol 3:683-693.

Sen S (1992) Programmed cell death: concept, mechanism and controls. Biol Rev 67:287-319.

Shindler KS, Roth KA (1996) Double immunofluorescent staining using two unconjugated primary antisera raised in the same species. J Histochem Cytochem 11:1331-1335.

Sloan HE, Hughes E, Oakley B (1983) Chronic impairment of axonal transport eliminates taste responses and taste buds. J Neurosci 3:117-123.

Son YJ, Thompson WJ (1995a) Schwann cell processes guide regeneration of peripheral axons. Neuron 14:125-132.
Son YJ, Thompson WJ (1995b) Nerve sprouting in muscle is induced and guided by processes extended by Schwann cells. Neuron 14:133-141.

Son YJ, Trachtenberg JT, Thompson WJ (1996) Schwann cells induce and guide sprouting and reinnervation of neuromuscular junctions. Trends Neurosci 19:280-285.

Spencer PS, Schaumburg HH (1973) An ultrastructural study of the inner core of the Pacinian corpuscle. J Neurocytol 2:217-235.

Strasmann T, Weihe E, Halata, Z (1990) CGRP-like immunoreactivity in sensory nerve ending of the Golgi tendon organ. Acta Anat 137:278-281.

Takahashi S (1995) Pacinian corpuscles in the articular capsule of the mouse knee joint, with special reference to postnatal development. Hokkaido Igaku Zasshi 70:159-173.

Torrey TW (1934) The relation of taste buds to their nerve fibers. J Comp Neurol 59:203.

Trachtenberg JT, Thompson WJ (1996) Schwann cell apoptosis at developing neuromuscular junctions is regulated by glial growth factor. Nature 379:174-177.

Vartanian T, Goodearl A, Viehover A, Fischbach G (1997) Axonal neuregulin signals cells of the oligodendroxyte lineage through activation of HER4 and Schwann cells through HER2 and HER3. J Cell Biol 137:211-220.

Vega JA, Zubizarreta JJ, del Valle ME (1990) Immunohistochemical study of cat Pacinian corpuscles: co-localization of vimentin-and S-100 protein-like in the inner core. Cell Mol Biol 36:415-420.

Verdi JM, Groves AK, Farinas I, Jones K, Marchionni MA, Reichardt LF, Anderson DJ (1996) A reciprocal cell-cell interaction mediated by NT-3 and neuregulins controls the early survival and development of sympathetic neuroblasts. Neuron 16:515-527.

Wen D, Peles E, Cupples R, Suggs SV, Bacus SS, Luo Y, Trail G, Hu S, Silbiger SM, Levy RB, Koski RA, Lu HS, Yarden Y (1992) Neu differentiation factor: a transmembrane glycoprotein containing an EGF domain and an immunoglobulin homology unit. Cell 69:559-572.

Wyllie AH (1987) Apoptosis: cell death in tissue regulation. J Pathol 153:313-316.

Zelená J (1964) Development, degeneration and regeneration of receptor organs. Prog Brain Res 13:175-211.

Zelená J (1976) The role of sensory innervation in the development of mechanoreceptors. Prog Brain Res 43:59-64.

Zelená J (1978) The development of Pacinian corpuscles. J Neurocytol 7:71-91.

Zelená J (1980) Rapid degeneration of developing rat pacinian corpuscles after denervation. Brain Res 187:97-111.

Zelená J (1981) Multiple innervation of rat Pacinian corpuscles regenerated after neonatal axotomy. Neuroscience 6:1675-1686.

Zelená J (1982) Survival of Pacinian corpuscles after denervation in adult rats. Cell Tissue Res 224:673-683.

Zelená J (1994) Nerves and mechanoreceptors: the role of innervation in the development and maintenance of mammalian mechanoreceptors. London: Chapman and Hall.

Zelená J, Hnik P (1963a) Motor and receptor units in the soleus muscle after nerve regeneration in very young rats. Physiol Bohemoslov 12:277-290.

Zelená J, Hnik P (1963b) Effect of innervation on the development of muscle receptors. In: The effect of use and disuse on neuromuscular functions (Gutmann E, Hnik P, eds), pp 95-105. Prague: Academia.

Zelená J, Soukup T (1977) The development of Golgi tendon organs. J Neurocytol 6:171-194.

Zelená J, Sobotkova M, Zelená H (1978) Age-modulated dependence of Pacinian corpuscles upon their sensory innervation. Physiol Bohemoslov 27:437-443. 